\title{
PENGARUH MEDIA PEMBALAJARAN LEAFLET TERHADAP HASIL BELAJAR BIOLOGI
}

\author{
Evi Purnama Sari ${ }^{1}$ \\ Universitas Muslim Maros, evipurnamasari1208@gmail.com \\ Syamsuriana Basri ${ }^{2}$, Kasmawati ${ }^{3}$ \\ Universitas Muslim Maros, SyamsurianaBasri138@gmail.com. \\ Kasmawati234@gmail.com
}

\begin{abstract}
Abstrak
Penelitian ini merupakan penelitian quasi eksperimen yang bertujuan untuk mengetahui apakah terdapat pengaruh leaflet terhadap hasil belajar biologi siswa kelas X di SMAS Angkasa Maros. Jenis penelitian ini adalah penelitian kuantitatif dengan desain Nonequivalent Control Group Design. Teknik Pengambilan sampel yaitu purposive sampling dengan pertimbangan tertentu yakni kemampuan kognitif rata-rata yang sama sampel dalam penelitian ini adalah Kelas X MIA 3 terdiri dari 37 orang sebagai kelas eksperimen dan Kelas X MIA 4, terdiri dari 36 orang sebagai kelas kontrol. Data dianalisis menggunakan uji $\mathrm{t}$ independen untuk melihat pengaruh leaflet terhadap hasil belajar siswa Kelas X di SMAS Angkasa Maros pada materi perubahan lingkungan, limbah dan daur ulang. Hasil penelitian menunjukkan bahwa rata-rata nilai hasil belajar biologi siswa pada kelas eksperimen sebesar 90,15 lebih tinggi dibandingkan dengan kelas kontrol yang hanya mendapatkan nilai rata-rata sebesar 85,91. Berdasarkan hasil analisis SPSS Versi 25 uji t diperoleh nilai sig 2(tailed) $0,000<0,05$ maka $\mathrm{H}_{0}$ di tolak dan $\mathrm{H}_{1}$ diterima. Sementara $\mathrm{t}_{\text {hitung }}>\mathrm{t}_{\text {tabel }}$ atau 5,031 $>1,99773$ maka $\mathrm{H}_{0}$ ditolak dan $\mathrm{H}_{1}$ diterima yang berarti ada pengaruh yang signifikan penggunaan leaflet terhadap hasil belajar biologi siswa kelas X SMAS Angkasa Maros pada materi perubahan lingkungan, limbah dan daur ulang.
\end{abstract}

\begin{abstract}
This research is a quasi-experimental research which aims to determine whether there is an effect of leaflets on the biology learning outcomes of class X students at the Angkasa Maros Senior High School. This type of research is a quantitative study with the design Nonequivalent Control Group Design. The sampling technique was purposive sampling with certain considerations, namely the same average cognitive ability. The sample in this study was Class X MIA 3 consisting of 37 people as the experimental class and Class X MIA 4, consisting of 36 people as the control class. The data were analyzed using the independent $t$ test to see the effect of the leaflet on the learning outcomes of Class X students at the Maros Angkasa High School on environmental change, waste and recycling materials. The results showed that the average score of students' biology learning outcomes in the experimental class was 90.15 higher than the control class which only got an average score of 85.91. Based on the results of the SPSS Version 25 t-test analysis, the sig 2 (tailed) value of $0.000<0.05$ was obtained, so $\mathrm{H}_{0}$ was rejected and $\mathrm{H}_{1}$ was accepted. While tcount $>$ ttable or $5.031>1.99773$ then $\mathrm{H}_{0}$ is rejected and $\mathrm{H}_{1}$ is accepted, which means that there is a significant effect of the use of leaflets on the
\end{abstract}


biology learning outcomes of class X students of SMAS Angkasa Maros on environmental change, waste and recycling materials.

Kata Kunci: Media Leaflet, Hasil Belajar

\section{PENDAHULUAN}

Dalam proses pembelajaran Pendidik bertindak sebagai fasilitator dan motivator. Pendidik sebagai fasilitator artinya Pendidik senantiasa memberikan fasilitas dan kemudahan dalam proses pembelajaran, sedangkan sebagai motivator berarti Pendidik meningkatkan kegairahan dan pengembangan kegiatan belajar peserta didik. Pendidik harus mampu memberikan dorongan untuk mendinamiskan potensi, aktivitas, dan kreativitas sehingga akan terjadi dinamika di dalam proses pembelajaran (Sanjaya,W, 2006). Belajar merupakan proses aktif siswa dalam membangun dan memahami konsep - konsep yang dikembangkan dalam kegiatan belajar mengajar baik secara individual maupun kelompok, mandiri maupun dibimbing (Arifin, dkk, 2005).

$$
\text { Bahan ajar yang bervariasi }
$$
merupakan kreatifitas seorang pendidik atau guru untuk membantu siswa memahami dan menyerap materi pembelajaran. Bahan ajar sangat berperan penting di dalam proses pembelajaran maka dari itu bahan ajar harus dipersiapkan agar pelaksanaan pembelajaran dan materi yang akan diberitahukan dapat mencapai sasaran. (Murti, W \& Anas, M, 2020).

Proses belajar mengajar juga sangat didukung oleh kemampuan atau keahlian guru dalam menyiapkan bahan ajar tersebut dimana guru yang profesional dituntut untuk memiliki kompetense-kompetensi tersebut dengan baik, serta memiliki pengalaman yang kaya di bidangnya (Kunandar, 2007).

Media atau bahan pembelajaran memiliki beberapa jenis yaitu; media cetak, media audio, media visual, media video, multimedia, dan perangkat komputer. Media atau bahan pembelajaran yang menjadi titik pusat peneliti adalah media cetak atau selebaran, media cetak merupakan alat atau media sederhana dan mudah diperoleh dan ditemukan dimana dan kapan saja. media atau bahan cetak bisa berupa buku, brosur, leaflet, modul, lembar kerja siswa, dan handout. Media atau bahan ajar cetak yang menjadi pusat penelitian adalah bahan ajar leaflet.

Menurut Sudirman (dalam Syamsuriana, 2016:7) Belajar dan 
mengajar sebagai aktivitas utama di sekolah meliputi tiga unsure, yaitu tujuan pengajaran, pengalaman belajar mengajar dan hasil belajar. Bahan ajar merupakan materi yang akan dijelaskan pada proses pembelajaran. Jika bukan karena bahan ajar proses pembelajaran tidak berjalan sesuai rencana. Karena itu, guru yang akan mendidik harus punya dan memahami betul bahan ajar yang akan disampaikannya pada siswa, (Djamarah, 2010).

Penggunaan bahan pembelajaran atau media saat proses belajar mengajar mempunyai peran penting. Peran tersebut menurut Belawati, (2003) melingkupi fungsi guru terhadap siswa saat proses belajar mengajar besar, sendiri, maupun kelompok. supaya didapatkan pengetahuan yang tambah jelas akan dijelaskan secara berurut yaitu: Manfaat bagi guru antara lain: media pembelajaran untuk mempunyai fungsi ialah: (1) Mengurangi penggunaan waktu guru saat pembelajaran. (2) Mengganti fungsi guru sebagai pengajar selaku penyedia. (3) Membuat proses belajar mengajar berpotensi tambah berhasil dan aktif.

Leaflet merupakan salah satu bahan ajar berupa selebaran yang berisi keterangan atau informasi tentang perusahaan, produk, organisasi dan jasa atau ide untuk diketahui oleh umum. Leaflet adalah selebaran yang serupa dengan kertas, kebanyakan format leaflet berukuran kecil dibanding pamphlet (Wijayanti, 2016). Suatu alternatif bahan pelajaran yang memesona sehingga siswa tidak bosan, sekaligus dapat meningkatkan aktivitas siswa dalam belajar yang dapat memberikan dampak positif terhadap hasil belajar siswa. Bahan ajar yang diduga efektif adalah bahan ajar leaflet. Leaflet bagaikan bahan pelajaran berbentuk cetak yang isinya rangkuman pokok materi pelajaran. Materi pelajaran tersebut dapat diambil dari berbagai sumber materi baik buku maupun internet yang dijadikan satu dalam bentuk leaflet ini. Leaflet terlihat menarik apabila dibuat dengan teliti ditambahkan juga ilustrasi/gambar-gambar dan memakai bahasa yang gampang, tidak bertele-tele dan mudah dipahami. Leaflet juga memiliki manfaat untuk dijadikan referensi dan bahan diskusi pada proses pembelajaran (Ameliawati, 2014). Selain itu Isi pesan atau informasi pada leaflet harus dapat dipahami dengan baik oleh yang membacanya (Jalaluddin, 2002).

Penelitian sebelumnya juga mengemukakan bahwa penggunaan 
bahan ajar leaflet dengan metode discovery berpengaruh dalam meningkatkan aktivitas belajar dan penguasaan materi pokok ekosistem (Hamid, A.A, 2014).

Menurut Ahmad \& Maulana, M. (2017) dan Akhmad, S. (2008) untuk itu perlu adanya terobosan baru dalam memvariasikan bahan ajar yang menarik sebagai media bantu bagi guru. Sumber belajar sebagai acuan siswa dengan harapan dapat meningkatkan hasil belajar siswa yang terlihat dari kemampuan untuk membaca sumbersumber belajar dan akhirnya berdampak untuk meningkatkan hasil belajar siswa salah satu upaya yang bisa dilakukan untuk meningkatkan hasil belajar siswa dengan penggunaan bahan ajar bentuk leaflat. Hasil belajar menurut Sudjana (2004) adalah kemampuan-kemampuan yang dimiliki siswa setelah siswa menerima pengalaman belajar yang diperoleh di di jenjang pendidikan. Agar terlihat menarik leaflet di desain dengan teliti, cermat dan dilengkapi gambar serta menggunakan kosa kata atau bahasa yang gampang atau mudah di pahami.

\section{METODE PENELITIAN}

Menurut Sugiyono 2006, penelitian eksperimen adalah metode penelitian yang digunakan untuk mencari pengaruh perlakuan tertentu dalam kondisi yang terkendalikan. Jenis penelitian yang digunakan adalah penelitian kuantitatif dengan metode Quasy Experiment. Penelitian ini membandingkan dua kelas yang diberi perlakuan dengan menggunakan bahan ajar leaflet dan metode konvensional, kemudian membandingkan hasil dari kedua perlakuan yang berbeda. Hal ini bertujuan untuk mengetahui perbedaan hasil belajar siswa setelah diadakannya perlakuan.

Desain penelitian ini menggunakan Non-equivalent Control Grup Design, desain ini hampir sama dengan Pretest-posttest control group design, hanya pada desain ini kelas eksperimen maupun kelas kontrol tidak dipilih secara random. Secara rinci Nonequivalent Control Group Desain (Sugiyono, 2011), dapat dilihat pada tabel berikut ini:

Tabel 1: desain penelitian

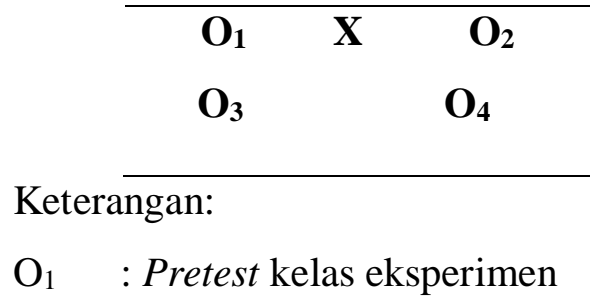


$\mathrm{O}_{2} \quad$ : Posttes kelas eksperimen

$\mathrm{O}_{3} \quad$ : Pretest kelas kontrol

$\mathrm{O}_{4} \quad$ : Posttes kelas kontrol

$\mathrm{X}$ : Perlakuan dengan penggunaan

bahan ajar leaflet

Populasi adalah sekumpulan dari individu dengan kualitas serta ciri-ciri yang ditetapkan (Subana,2005). Populasi dalam penelitian ini adalah seluruh siswa kelas X MIA SMAS Angkasa Maros yang berjumlah 181 orang siswa. Sampel yang diambil dalam penelitian ini sebanyak dua kelas. Dalam pengambilan kelas eksperimen dan kontrol, teknik sampling yang digunakan adalah teknik Purposive sampling. Terknik ini digunakan karena pertimbangan bahwa kedua kelompok sampel memiliki kemampuan kognitif rata-rata yang sama. Penulis meminta kepada pihak sekolah sebagai guru mata pelajaran biologi yang memahami karakteristik siswa di sekolah tersebut untuk menentukan kelas yang akan dijadikan sampel. Populasi dalam penelitian ini adalah seluruh siswa kelas $\mathrm{X}$ MIA SMAS Angkasa Maros berjumlah 5 kelas sebanyak 181 orang siswa, sampel dalam penelitian ini adalah Kelas X MIA 3 terdiri dari 37 orang sebagai kelas eksperimen dan Kelas X MIA 4 terdiri dari 36 orang sebagai kelas kontrol.
Teknik pengumpulan data berupa observasi, tes, interview dan dokumentasi. Observasi digunakan untuk mengetahui kegiatan belajar mengajar berlangsung melalui pengamatan secara daring melalui aplikasi Whats App. Metode Tes digunakan untuk memperoleh data hasil belajar siswa kelas X MIA 3 dan X MIA 4 semester dua melalui pemberian Pretest (tes awal) dan Posttest (tes akhir) pada kelas X MIA 3 (kelas Eksperimen) dan pada kelas X MIA 4 (kelas Kontrol) melalui pembelajaran daring. Metode interview ini digunakan untuk mendapatkan data mengenai bahan ajar leaflet yang di gunakan wawancara dilakukan secara daring. Tujuannya untuk mengetahui respon siswa dengan digunakannya bahan ajar leaflet ini apakah sangat membantu atau malah sebaliknya.

Dokumentasi merupakan mencari data mengenai hal-hal atau variabel yang berupa catatan, buku, dokumen sekolah, peraturan-peraturan dan sebagainya.

Data yang diperoleh kemudian dianalisis yaitu analisis deskriptif dan inferensial. Statistik deskriptif digunakan untuk mendeskripsikan karakteristik responden antara lain berupa rata-rata, min, max, variasi dan standar deviasi 
responden pada kelas eksperimen dan kelas kontol. Analisis inferensial terdiri dari uji prasyarat yakni Uji normalitas dan homogenitas dengan bantuan program SPSS versi 25.

Data yang telah dikumpulkan, selanjutnya dianalisis secara kuantitatif. Data yang diperoleh dari hasil validasi oleh para ahli dianalisis untuk menjelaskan kevalidan instrument media laboratorium virtual berbasis android mobile. Adapun data hasil ujicoba yaitu pengambilan data melalui lembar observasi keterlaksanaan media tersebut digunakan untuk menjelaskan kepraktisan penggunaan media. Berikut ini dikemukakan tentang analisis data dari penelitian ini. Untuk mengetahui nilai yang diperoleh mahasiswa, maka skor diubah ke nilai (Arikunto, 2009).

Uji-t Dalam penelitian ini digunakan analisis statistik uji-t sampel independent dua pihak dengan taraf signifikan $(\alpha)=0,05$ yang kaidah pengujiannya sebagai berikut : Jika thitung> ttabel maka $\mathrm{H} 0$ ditolak dan $\mathrm{H} 1$ diterima Jika thitung $\leq$ ttabel maka $\mathrm{H} 0$ diterima H1 ditolak. Menguji hipotesis digunakan menurut Meltzer (2002), untuk mengukur pengaruh suatu pembelajaran berdasarkan adanya peningkatan dari pretest ke posttest maka digunakan gain ternormalisasi. Analisis gain ternormalisasi digunakan untuk mengetahui kriteria normalisasi gain yang dihasilkan. Semakin besar nila $\mathrm{N}$ Gain yang diperoleh mahasiswa, semakin besar pula perubahan yang telah dialami oleh mahasiswa. Hal ini berarti semakin besar pula pengaruh model pembelajaran yang telah diberikan kepada mahasiswa

\section{HASIL DAN PEMBAHASAN}

Berdasarkan penelitian yang telah dilakukan di SMA Angkasa Maros dengan menggunakan bahan ajar leaflet untuk mengetahui pengaruhnya terhadap hasil belajar biologi kelas X pada materi pokok perubahan lingkungan, limbah dan daur ulang, maka didapatkan hasil penelitian yang terdiri atas: data hasil belajar dan tanggapan siswa terhadap hasil penggunaan bahan ajar leaflet.Untuk mengetahui kategori hasil belajar kelas eksperimen (X MIA 3) dengan cara memberikan tes kepada siswa. Kemudian pertemuan dilakukan sebanyak 2 kali, pemberian pre-test dilakukan pada pertemuan pertama dan post-test dilakukan pada pertemuan kedua. Hasil analisis deskriptif sebagai berikut: 
Tabel 2. Nilai Statistik Deskriptif pada pretest kelas Eksperimen dan control

\begin{tabular}{lcc}
\hline & $\begin{array}{c}\text { Kelas } \\
\text { Eksperimen }\end{array}$ & $\begin{array}{c}\text { Kelas } \\
\text { Kontrol }\end{array}$ \\
\hline $\mathrm{N}$ & 33 & 33 \\
\hline Range & 10 & 9 \\
\hline Minimum & 75 & 75 \\
\hline Maximum & 85 & 84 \\
\hline Mean & 79,67 & 79,06 \\
\hline Std. & 2,976 & 2,609 \\
Deviasi & & \\
\hline
\end{tabular}

Tabel 3. Nilai Statistik Deskriptif pada Posttest kelas eksperimen dan kontrol

\begin{tabular}{lcc}
\hline & $\begin{array}{c}\text { Kelas } \\
\text { Eksperimen }\end{array}$ & $\begin{array}{c}\text { Kelas } \\
\text { Kontrol }\end{array}$ \\
\hline $\mathrm{N}$ & 33 & 33 \\
\hline Range & 16 & 15 \\
\hline Minimum & 80 & 78 \\
\hline Maximum & 96 & 93 \\
\hline Mean & 90,15 & 85,91 \\
\hline Std. & 3,365 & 3,485 \\
Deviation & & \\
\hline
\end{tabular}

Tabel 4. Distribusi dan Frekuensi Hasil Belajar Biologi Siswa Kelas Eksperimen dan Kelas Kontrol

\begin{tabular}{|c|c|c|c|c|}
\hline \multirow{2}{*}{$\begin{array}{c}\text { Skor } \\
\text { Hasil } \\
\text { Belajar } \\
\text { Biologi } \\
\text { Siswa }\end{array}$} & \multirow{2}{*}{ Kategori } & \multirow{2}{*}{$\begin{array}{c}\text { Titik } \\
\text { Teng } \\
\text { ah }\end{array}$} & \multicolumn{2}{|c|}{ Frekuensi } \\
\hline & & & Eksp. & $\begin{array}{c}\text { Kont } \\
1 .\end{array}$ \\
\hline $78-81$ & $\begin{array}{l}\text { Sangat } \\
\text { Rendah }\end{array}$ & 79,5 & 1 & 4 \\
\hline $82-85$ & Rendah & 83,5 & 2 & 11 \\
\hline $86-89$ & Sedang & 87,5 & 10 & 13 \\
\hline $90-93$ & Tinggi & 91,5 & 14 & 5 \\
\hline $94-97$ & $\begin{array}{l}\text { Sangat } \\
\text { Tinggi }\end{array}$ & 95,5 & 6 & 0 \\
\hline
\end{tabular}

Tabel 5. Distribusi Tingkat Ketuntasan Hasil Belajar

\begin{tabular}{ccc}
\hline No. & $\begin{array}{c}\text { Kategori } \\
\text { Ketuntasan }\end{array}$ & Keterangan \\
\hline 1. & $>75$ & Tuntas \\
\hline 2. & $<75$ & Tidak \\
& & Tuntas \\
\hline
\end{tabular}

Tabel 6. Hasil Uji Normalitas

\begin{tabular}{|c|c|c|c|c|c|c|}
\hline \multirow[b]{2}{*}{ Kelas } & \multicolumn{3}{|c|}{$\begin{array}{c}\text { Kolmogorov- } \\
\text { Smirnov }^{\text {a }}\end{array}$} & \multicolumn{3}{|c|}{ Shapiro-Wilk } \\
\hline & $\begin{array}{l}\text { Sta } \\
\text { tist } \\
\text { ic }\end{array}$ & Df & $\begin{array}{c}\text { Sig } \\
.\end{array}$ & $\begin{array}{c}\text { Sta } \\
\text { tist } \\
\text { ic }\end{array}$ & Df & Sig. \\
\hline Pretest Kelas &, 10 & 33 & ,20 & ,95 & 33 &, 15 \\
\hline Eksperimen & 6 & & $0^{*}$ & 2 & & 2 \\
\hline Posttest &, 12 & 33 & ,20 & ,95 & 33 & 15 \\
\hline $\begin{array}{l}\text { Kelas } \\
\text { Eksperimen }\end{array}$ & 4 & & $0^{*}$ & 2 & & 7 \\
\hline Pretest Kelas &, 11 & 33 & 20 & ,95 & 33 & , 13 \\
\hline Kontrol & 2 & & $0^{*}$ & 0 & & 7 \\
\hline Posttest &, 15 & 33 & ,04 & ,95 & 33 & 23 \\
\hline $\begin{array}{l}\text { Kelas } \\
\text { Kontrol }\end{array}$ & 5 & & 4 & 9 & & 5 \\
\hline
\end{tabular}

Tabel 7. Hasil uji Homogentitas

\begin{tabular}{llr|r|r|r} 
& & $\begin{array}{r}\text { Sta } \\
\text { tist }\end{array}$ & d & & \\
& & ic & $\mathbf{1}$ & df2 & \multicolumn{1}{c}{ Sig } \\
\hline $\begin{array}{l}\text { Hasil } \\
\text { belaj } \\
\text { ar } \\
\text { siswa }\end{array}$ & Based on Mean &, 16 & 1 & 64 &, 68 \\
& & 5 & & & 6 \\
\cline { 2 - 7 } & Based on Median &, 19 & 1 & 64 &, 65 \\
& Based on Median &, 19 & 1 & 63,8 &, 65 \\
& and with adjusted & 8 & & 49 & 8 \\
& df & & & & \\
\cline { 2 - 7 } & Based on &, 11 & 1 & 64 &, 73 \\
& trimmed mean & 4 & & & 7 \\
\hline
\end{tabular}

Tabel 8. Hasil Uji Hipotesis

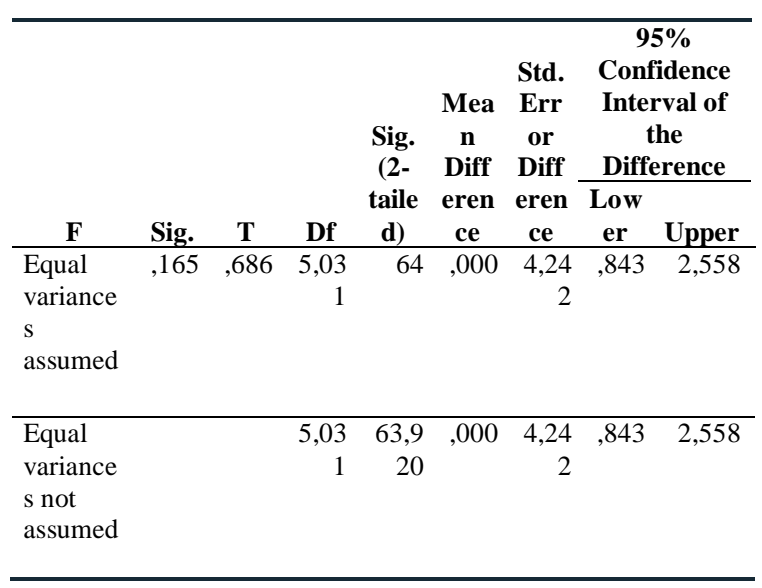

Hasil pengujian hipotesis penelitian, dapat di peroleh tingkat 
signifikan dari pengujian ini sebesar 5\% $(0,05)$. Dasar pengambilan keputusan terhadap hipotesis yang diajukan adalah nilai sig. 2(tailed) $<0.05$ maka $\mathrm{H}_{0}$ ditolak. Dapat dilihat dari tabel nilai sig (2-tailed) $0,000<0,05$ dimana nilai ini lebih kecil dari 0,05 maka $\mathrm{H}_{0}$ di tolak dan $\mathrm{H}_{1}$ diterima. Maka dapat disimpulkan bahwa diketahui penggunaan bahan ajar leaflet berpengatuh terhadap hasil belajar biologi siswa. Sementara pada $t_{\text {tabel }}$ menujukkan 1,66901 pada taraf signifikansi $\quad 5 \% \quad$ sedangkan $\quad t_{\text {hitung }}$ menunjukkan 5,031. Dengan demikian $\mathrm{t}_{\text {hitung }}>\mathrm{t}_{\text {tabel }}$ atau 5,031 $>1,66901$ yang berarti $\mathrm{H}_{0}$ ditolak dan $\mathrm{H}_{1}$ yang berarti ada pengaruh yang signifikan terhadap penggunaan bahan ajar leaflet terhadap hasil belajar biologi siswa.

Berdasarkan penelitian yang dilakukan pada kelas X MIA 3 yang pembelajarannya menggunakan bahan ajar leaflet selama 2(dua) kali pertemuan yang masing-masing pertemuan memiliki alokasi waktu $3 \times 45$ menit dengan materi perubahan lingkungan, limbah dan daur ulang. Bahan ajar leaflet dilakukan dengan tahap yaitu pembagian kelompok, penyajian materi, dan kesimpulan setiap kelompok melalui via whatsapp. Pada penelitian ini, peneliti memberikan tes yang berupa soal essay sebanyak 10 butir yang akan peneliti olah datanya yang diperoleh dari hasil tes tersebut yang digunakan sebagai tes kemampuan untuk mengetahui hasil belajar siswa dengan bantuan bahan ajar leaflet, kemudian peneliti melakukan pengujian analisis statistik deskriptif. Pada pemberian pre-test diperoleh nilai terendah yaitu 65 dan nilai tertinggi 85 dengan rata-rata 79,67 dan standar deviasi 2,976. Kemudian pada post test diperoleh nilai terendah 80 dan nilai tertinggi 96 dengan rata-rata 90,15 dan standar deviasi 3,365.

Dari hasil pengolahan data diatas dapat disimpulkan bahwa hasil belajar biologi siswa kelas X MIA 3 sebagai kelas eksperimen yang pembelajarannya menggunakan bahan ajar leaflet baik dalam peningkatan hasil belajar siswa. Peningkatan yang terjadi pada hasil belajar siswa karena bantuan bahan ajar leaflet yang membuat siswa lebih kreatif berargumen atau mengeluarkan ide-ide dan gagasan mereka dalam bekerja sama terhadap materi yang dipelajari dalam berkelompok, mereka mampu menyampaikan segala bentuk idenya baik dalam kelompok maupun diluar kelompoknya. Berdasarkan hasil 
wawancara yang telah dilakukan peneliti terhadap kelas eksperimen (X MIA 3) pembelajaran menggunakan bahan ajar leaflet ini sangat membantu, kebanyakan siswa lebih suka dengan mennggunakan bahan ajar leaflet ini, siswa lebih memahami materi yang di bagikan guru melalui bahan ajar ini. Pembelajaran dengan bahan ajar leaflet ini menurut siswa tidak membosankan dan membuat siswa lebih bersemangat dan melatih siswa untuk berargumen dan bekerjasama dalam berkelompok. Hal ini yang menyatakan bahwa pembelajaran dengan menggunakan bahan ajar leaflet membuat siswa lebih kreatif dan terampil dalam berargumen baik di dalam kelompok maupun diluar kelompok sehingga mempengaruhi hasil belajar siswa menjadi lebih baik.

Berdasarkan penelitian yang dilakukan pada kelas X MIA 4 yang pembelajarannya menggunakan model komvensional dengan 2(dua) kali pertemuan masing-masing memiliki alokasi waktu $3 \times 45$ menit dengan materi perubahan lingkungan, pelestarian dan daur ulang. Pada penelitian ini, peneliti memberikan soal essay sebanyak 10 butir yang akan peneliti olah datanya yang diperoleh dari hasil tes tersebut yang digunakan sebagai tes kemampuan untuk mengetahui hasil belajar siswa sekaligus tingkat penguasaan materi siswa, maka peneliti melakukan pengujian analisis statistik deskriptif. Pada hasil pre-test diperoleh nilai terendah 75 dan nilai tertinggi 84 dengan rata-rata 79,06 dan standar deviasi 2,609. Kemudian pada post test diperoleh nilai terendah 78 dan nilai tertinggi 93 dengan rata-rata 85,91 dan standar deviasi 3,485.

Dari hasil pengolahan data diatas dapat disimpulkan bahwa hasil belajar biologi siswa pada kelas X MIA 4 dengan menggunakan model pembelajaran konvensional kurang baik dalam meningkatkan hasil belajar peserta didik disebabkan karena guru lebih mendominasi dalam model pembelajaran ini, sedangkan siswa hanyak mendengarkan dan memperhatikan materi apa yang disampaikan guru dan ini sangat membosankan bagi siswa.

Selama proses proses pembelajaran dengan menggunakan bahan ajar leaflet pada kelas eksperimen berlangsung dengan kondusif. Berdasarkan hasil hipotesisi yang didapatkan dengan menggunakan uji independent sampel test didapatkan nilai $\mathrm{t}_{\text {hitung }}>\mathrm{t}_{\text {tabel }}$ atau 5,031 $>1,66901$ yang 
berarti $\mathrm{H}_{0}$ ditolak dan $\mathrm{H}_{1}$ yang berarti ada pengaruh yang signifikan terhadap penggunaan bahan ajar leaflet terhadap hasil belajar biologi siswa. Berdasrkan perolehan pengkategorian nilai post test kelas eksperimen hasil belajar yang diperoleh siswa berkategori tinggi. Dengan demikian penggunaan bahan ajar leaflet terhadap hasil belajar siswa terdapat pengaruh. Namun di dalam penelitian ini keseluruhan sampel yang digunakan untuk masing-masing kelas kontrol dan kelas eksperimen 33 siswa atau 66 sampel disebabkan karena ketidakhadiran 6 siswa dalam mengikuti pembelajaran pada saat penelitian. Hasil Belajar Biologi Siswa Kelas Eksperimen (X MIA 3) SMAS Angkasa Maros yang pembelajarannya Menggunakan Bahan Ajar Leaflet.

Berdasarkan penelitian yang dilakukan pada kelas X MIA 3 yang pembelajarannya menggunakan bahan ajar leaflet selama 2(dua) kali pertemuan yang masing-masing pertemuan memiliki alokasi waktu $3 \times 45$ menit dengan materi perubahan lingkungan, limbah dan daur ulang. Bahan ajar leaflet dilakukan dengan tahap yaitu pembagian kelompok, penyajian materi, dan kesimpulan setiap kelompok melalui via whatsapp. Pada penelitian ini, peneliti memberikan tes yang berupa soal essay sebanyak 10 butir yang akan peneliti olah datanya yang diperoleh dari hasil tes tersebut yang digunakan sebagai tes kemampuan untuk mengetahui hasil belajar siswa dengan bantuan bahan ajar leaflet, kemudian peneliti melakukan pengujian analisis statistik deskriptif. Pada pemberian pre-test diperoleh nilai terendah yaitu 65 dan nilai tertinggi 85 dengan rata-rata 79,67 dan standar deviasi 2,976. Kemudian pada post test diperoleh nilai terendah 80 dan nilai tertinggi 96 dengan rata-rata 90,15 dan standar deviasi 3,365.

Dari hasil pengolahan data diatas dapat disimpulkan bahwa hasil belajar biologi siswa kelas X MIA 3 sebagai kelas eksperimen yang pembelajarannya menggunakan bahan ajar leaflet baik dalam peningkatan hasil belajar siswa. Peningkatan yang terjadi pada hasil belajar siswa karena bantuan bahan ajar leaflet yang membuat siswa lebih kreatif berargumen atau mengeluarkan ide-ide dan gagasan mereka dalam bekerja sama terhadap materi yang dipelajari dalam berkelompok, mereka mampu menyampaikan segala bentuk idenya baik dalam kelompok maupun diluar kelompoknya. Berdasarkan hasil 
wawancara yang telah dilakukan peneliti terhadap kelas eksperimen (X MIA 3) pembelajaran menggunakan bahan ajar leaflet ini sangat membantu, kebanyakan siswa lebih suka dengan mennggunakan bahan ajar leaflet ini, siswa lebih memahami materi yang di bagikan guru melalui bahan ajar ini. Pembelajaran dengan bahan ajar leaflet ini menurut siswa tidak membosankan dan membuat siswa lebih bersemangat dan melatih siswa untuk berargumen dan bekerjasama dalam berkelompok. Hal ini yang menyatakan bahwa pembelajaran dengan menggunakan bahan ajar leaflet membuat siswa lebih kreatif dan terampil dalam berargumen baik di dalam kelompok maupun diluar kelompok sehingga mempengaruhi hasil belajar siswa menjadi lebih baik. Hasil Belajar Biologi Siswa Kelas Kontrol (X MIA 4) SMA Angkasa Maros dengan Menggunakan Model Pembelajaran Komvensional.

Berdasarkan penelitian yang dilakukan pada kelas X MIA 4 yang pembelajarannya menggunakan model komvensional dengan 2(dua) kali pertemuan masing-masing memiliki alokasi waktu $3 \times 45$ menit dengan materi perubahan lingkungan, pelestarian dan daur ulang. Pada penelitian ini, peneliti memberikan soal essay sebanyak 10 butir yang akan peneliti olah datanya yang diperoleh dari hasil tes tersebut yang digunakan sebagai tes kemampuan untuk mengetahui hasil belajar siswa sekaligus tingkat penguasaan materi siswa, maka peneliti melakukan pengujian analisis statistik deskriptif. Pada hasil pre-test diperoleh nilai terendah 75 dan nilai tertinggi 84 dengan rata-rata 79,06 dan standar deviasi 2,609. Kemudian pada post test diperoleh nilai terendah 78 dan nilai tertinggi 93 dengan rata-rata 85,91 dan standar deviasi 3,485.

Dari hasil pengolahan data diatas dapat disimpulkan bahwa hasil belajar biologi siswa pada kelas X MIA 4 dengan menggunakan model pembelajaran konvensional kurang baik dalam meningkatkan hasil belajar peserta didik disebabkan karena guru lebih mendominasi dalam model pembelajaran ini, sedangkan siswa hanyak mendengarkan dan memperhatikan materi apa yang disampaikan guru dan ini sangat membosankan bagi siswa.

Pengaruh Penggunaan Bahan Ajar Leaflet Terhadap Hasil Belajar Biologi Siswa Pada Materi Selama proses proses pembelajaran dengan 
menggunakan bahan ajar leaflet pada kelas eksperimen berlangsung dengan kondusif. Berdasarkan hasil hipotesis yang didapatkan dengan menggunakan uji independent sampel test didapatkan nilai $t_{\text {hitung }}>\mathrm{t}_{\text {tabel }}$ atau $5,031>1,66901$ yang berarti $\mathrm{H}_{0}$ ditolak dan $\mathrm{H}_{1}$ yang berarti ada pengaruh yang signifikan terhadap penggunaan bahan ajar leaflet terhadap hasil belajar biologi siswa. Berdasrkan perolehan pengkategorian nilai post test kelas eksperimen hasil belajar yang diperoleh siswa berkategori tinggi. Dengan demikian penggunaan bahan ajar leaflet terhadap hasil belajar siswa terdapat pengaruh. Namun di dalam penelitian ini keseluruhan sampel yang digunakan untuk masing-masing kelas kontrol dan kelas eksperimen 33 siswa atau 66 sampel disebabkan karena ketidakhadiran 6 siswa dalam mengikuti pembelajaran pada saat penelitian.

Adapun kelebihan dan kelemaham media leaflet pada saat penelitian adalah sebagai berikut: Kelebihan: Kelebihan pembelajaran menggunakan media leaflet dibandingkan dengan pembelajaran yang tidak menggunakan media leaflet adalah dengan media ini dapat membuat kegiatan pembelajaran menjadi lebih menarik perhatian siswa, siswa menjadi aktif bertanya dan menjawab pertanyaan peneliti, serta mampu mengembangkan pola pikirnya melalui diskusi kelompok. (Suprijono, A. 2009).

Selain itu, media leaflet mampu meningkatkan hasil belajar siswa dalam mengikuti kegiatan pembelajaran. Berbeda dengan pembelajaran sebelumnya yang cenderung membuat suasana pembelajaran menjadi monoton karena siswa hanya fokus memperhatikan guru menjelaskan materi. Akibatnya siswa menjadi bosan sehingga untuk menghilangkan kebosanan tersebut, siswa melakukan kegiatan yang tidak berkaitan dengan pembelajaran seperti mengajak teman sebangku untuk mengobrol, dan jika teman sebangkunya serius dalam mengikuti pembelajaran, dia memilih untuk tidur saat proses pembelajaran berlangsung. Meningkatnya hasil belajar siswa setelah pembelajaran eksperimen disebabkan oleh beberapa faktor sebagai berikut: siswa sangat tertarik pada media leaflet ini karena sebelumnya bahan ajar leaflet ini digunakan oleh guru sebagai pelengkap media lembar kerja siswa, media leaflet mempu meningkatakan minat baca siswa karena media leaflet menyajikan materi dengan penggunaan 
gambar, warna menarik serta bahasan yang mudah dipahami oleh pembaca.

Menurut Amri, S. dan I. K. Ahmadi. (2010) bahwa penggunaan media leaflet menjadikan siswa lebih termotovasi untuk belajar karena siswa harus menguasai materi agar dapat menjawab soal tes yang diberikan peneliti. Kelemahan: (a) Kelemahan penggunaan media leaflet pada pembelajaran dikelas antara lain: Tidak dapat menampilkan gerak dalam media leaflet. (b) Biaya percetakan mahal apabila ingin menampilkan ilustrasi, gambar, atau foto yang berwarna. (c) Proses percetakan media sering kali memakan waktu lama

\section{KESIMPULAN}

Setelah dilakukan penelitian dapat disimpulkan bahwa penggunaan bahan ajar leaflet berpengaruh terhadap hasil belajar siswa kelas X MIA 3 sebagai kelas eksperimen dalam pembelajaran biologi tingkat ketuntasan hasil belajar lebih tinggi dibandingkan kelas kontrol.

\section{UCAPAN TERIMA KASIH}

Terima kasih kami ucapkan selaku penulis artikel ini kepada seluruh pihak-pihak yang terkait dengan suksesnya tulisan ini terutama kepada pembimbing skripsi saya yang telah membimbing saya hingga tulisan ini bisa dipublikasikan dan kepada unsur pimpinan Universitas Muslim Maros yang telah memberikan saya wadah dalam melakukan penelitian ini.

\section{DAFTAR PUSTAKA}

Ahmad \& Maulana, M. 2017. pengembangan media pembelajaran berbasis leaflet padamateri sistem sirkulasi kelas XI MAN I Makassar. Alauddin Makassar. Skripsi. Program Sarjana Universitas Islam Negeri (Uin) Alauddin Makassar. http://repositori.uinalauddin.ac.id/8440/1/marwah\%20 ahmad\%20maulana.pdf

Akhmad, S. 2008. Model Pembelajaran Inovatif. Jurnal Kurikulum dan Pembelajaran (online). http://akhmadsudrajat.wordpress.c om/2008/01/19.

Ameliawati, D Jalmo, $\mathrm{T}$ \& Yolida, B 2014. Pengaruh penggunaan bahan ajar leaflet terhadap aktivitas dan hasil belajar siswa. Jurnal Bioterdidik: Wahana Ekspresi ilmiah 2 (5): 1-12 http://jurnal.fkip.unila.ac.id/index. $\mathrm{php/JBT/article/view/4060}$

Amri, S. dan I. K. Ahmadi. 2010. Proses Pembelajaran Kreatif dan Inovatif dalam Kelas. PT. Jakarta: Prestasi Pustakaraya.

Arifin, M, dkk. 2005. Strategi Belajar Mengajar. Universitas Negeri Malang. Malang. 
Arikunto, S. 2009. Dasar-dasar Evaluasi Pendidikan. Bumi Aksara. Jakarta

Basri, S 2016. Meningkatkan hasil belajar fisika melalui strategi learning tournament pada siswa kelas VIIc SMP Negeri 1 Tanralili Kabupaten Maros. Jurnal Ecosystem, 16 (3): 7-21 http://ecosystem.universitasbosow a.ac.id/index.php/eco/article/view/ $\underline{45}$

Belawati, T. 2003. Pengembangan Bahan Ajar . Jakarta. Pusat PenerbitanUT. http://ebookbrowsee.net/programpengayaan-docx-d504180619.

Djamarah, S. B dan A. Zain. 2010. Strategi Belajar Mengajar. Jakarta: Rineka Cipta.

Hamid, A. A., Sikumbang, D. \& Marpaung, R.R.T., 2014. Penggunaan Bahan Ajar Leaflet terhadap Aktivitas Belajar dan Penguasaan Materi oleh Siswa. Jurnal Bioterdidik Wahana Ekspresi Ilmiah, 2 (4): 1-13. https://core.ac.uk/download/pdf/28 9777912.pdf

Jalaludin. R. 2002. Psikologi komunikasi. Bandung. PT. Remaja Rosdakarya.

Kunandar. 2007. Guru Profesional. PT Rajagrafindo Persada. Jakarta.

Meltzer, D. 2002. The relationship between mathematics preparation and conceptual learning gains in physics: A possible "hidden variable" in diagnostic pretest scores American journal physics, $58 \quad$ (8): 734-741.

https://pdfs.semanticscholar.org/84 e5/e21fa60337453f5dfa9d6a05f53 a420e0863.pdf

Murti, W \& Anas, M. 2020. Efektivitas Pembelajaran Kooperatif Tipe Kancing Gemerincing (Talking Chips) Terhadap Hasil Belajar Mahasiswa. Jurnal Biotek. 8 (2): 80-94.

http://journal.uinalauddin.ac.id/index.php/biotek/art icle/view/16119

Sanjaya, W. 2006. Kurikulum dan Pembelajaran. Kencana Media Group. Jakarta

Subana. 2005. Statistik Pendidikan. CV Pustaka Setia. Bandung.

Sudjana. 2004. Penilaian Hasil Proses Belajar Mengajar. PT Remaja Rosdakarya. Bandung.

Suprijono, A. 2009. Coopertative Learning; Teori dan Aplikasi PIKEM. Jogjakarta. Pustaka Pelajar.

Sugiyono. 2006. Metode Penelitian Kuantitatif Kualitatif dan R\&D Alfabeta. Bandung.

Sugiyono. 2011. Metodologi Penelitian Pendidikan. Bandung: Alfabeta.

Wijayanti, A. 2016. Pengaruh penggunaan bahan ajar leaflet terhadaphasil belajar siswa pada materi pokok ekosistem. Skripsi Tidak Diterbitkan. Badar Lampung. Program Sarjana Universitas Lampung. http://digilib.unila.ac.id/25337/ 